\title{
Chitinase 3-Like 1 (CHI3L1) Polymorphism Contributes to Visceral Obesity and Obesity-related Inflammation Induces Chi3l1 in Adipocytes
}

\author{
A Young Kim ${ }^{1}$, Hyun Woo Jeong ${ }^{1}$, Ji-Hae Lee ${ }^{1}$, Jin Kyu Choi ${ }^{2}$, \\ Jeong Kee Kim ${ }^{3}$, Jae Sung Hwang ${ }^{3}$ and Dae-Bang Seo ${ }^{1, \dagger}$ \\ ${ }^{I}$ Vital Beautie Research Division, Amorepacific R\&D Center, Yongin 17074, Korea \\ ${ }^{2} Q A$ team, Aestura Corporation, Ansung 17573, Korea \\ ${ }^{3}$ Department of Genetic Engineering \& Graduate School of Biotechnology, College of Life Sciences, \\ Kyung Hee University, Yongin 17104, Korea
}

\begin{abstract}
Abdominal obesity is considered as one of the most risky factors governing the development of metabolic diseases. Here we identify that human chitinase 3-like 1 (CHI3L1, also called YKL-40 in human) single nucleotide polymorphism (SNP), rs883125, is associated with abdominal obesity in Korean women. Korean women subjects with the rs883125 $\mathrm{G} / \mathrm{G}$ or $\mathrm{C} / \mathrm{G}$ genotype present higher waist-hip ratio than subjects with $\mathrm{C} / \mathrm{C}$ genotype suggesting that human subjects who $\mathrm{G}$ nucleotide substitution at the rs 883125 tended to more accumulate intra-abdominal fat at the abdominal cavity. In addition, Chi3ll gene expression is increased in adipose tissue from obese mice and pro-inflammatory cytokine enhances Chi3ll expression in adipocytes, indicating that Chi3ll is greatly related with obesity and obesity-induced pro-inflammatory responses. Taken together, the minor allele of rs 883125 is associated with a higher prevalence of abdominal obesity in Korean women. These findings suggest that genotype of rs 883125 can be a biomarker of incident abdominal obesity and abdominal obesity-related metabolic diseases.
\end{abstract}

Key Words: Chitinase 3-like 1, CHI3L1, YKL-40, SNP, Abdominal obesity, Korean women

\section{INTRODUCTION}

For the several decades, the prevalence and severity of obesity is dramatically and continuously has increased worldwide. Obesity has become a major public health problem since it is one of the key factors for development of metabolic diseases such as insulin resistance, type 2 diabetes, atherosclerosis, and several cancers. Although obesity is considered as a lifestyle disease, it is substantially recognized that genetic factors are also involved in the pathogenesis of obesity (Herrera and Lindgren, 2010; Choquet and Meyre,
2011). Single nucleotide polymorphisms (SNPs) is represented these genetic factors that contribute to development of obesity. Many researchers have found SNPs, which are associated with obesity, and identified those SNPs are located in genes that involved in food intake, fat metabolism, adipocyte differentiation, and energy metabolism (Dina et al., 2007; Frayling et al., 2007; Loos et al., 2008; Lindgren et al., 2009; Meyre et al., 2009).

Abdominal fat, also known as visceral fat, is located in peritoneal cavity around the organs. Accumulation of excess energy as abdominal fat in adipocytes leads abdominal obesity and is a very high risk factor for cardiovascular diseases and

* Received: November 29, 2017 / Revised: March 12, 2018 / Accepted: March 13, 2018

${ }^{\dagger}$ Corresponding author: Dae-Bang Seo. Vital Beautie Research Division, Amorepacific R\&D Center, Youngin 17074, Korea.

Tel: +82-31-280-5975, Fax:+82-31-284-8392, e-mail: sdbang@amorepacific.com

(C) The Korean Society for Biomedical Laboratory Sciences. All rights reserved.

(c) This is an Open Access article distributed under the terms of the Creative Commons Attribution Non-Commercial License (http://creativecommons.org/licenses/by-nc/3.0/) which permits unrestricted non-commercial use, distribution, and reproduction in any medium, provided the original work is properly cited. 
type 2 diabetes (Despres et al., 2008). Increase of fat storage in visceral adipocytes changes their characteristics and functions such as production of cytokines (McArdle et al., 2013). Enlarged adipocytes produce and secret pro-inflammatory cytokines and chemo-attractant molecules, including tumor necrosis factor- $\alpha$ (TNF- $\alpha$ ), interleukin (IL)-1, IL-6, and monocyte chemotactic protein 1 (MCP1), in turn, induce a state of chronic low-grade inflammation with increase of infiltration of various immune cells into adipose tissue and lead alternation of whole body energy balance (Esser et al., 2014).

Chitinase 3-like 1 (CHI3L1, also called YKL-40 in human) is a chitinase-like glycoprotein, which binds to chitin but cannot degrade it because of mutations in their active domains (Rehli et al., 1997). CHI3L1 involves in tissue remodeling and immune responses through participating in M2 macrophage differentiation, inflammasome activation, and Th1/Th2 immune balance (Rehli et al., 2003). CHI3L1 is produced by various cells including macrophage and neutrophils (Krause et al., 1996; Volck et al., 1998). Additionally, circulating levels of CHI3L1 are increased in patients with inflammationrelated diseases including asthma, atrophy, liver fibrosis, atherosclerosis, and type 2 diabetes (T2DM) (Chupp et al., 2007; Lee et al., 2012). Furthermore, CHI3L1 expression is induced by inflammatory cytokines such as IL-6, INF- $\gamma$, and TNF $\alpha$ (Ling and Recklies, 2004). In contrast, CHI3L1 inhibits cellular responses induced by those cytokines, implying that enhancement of CHI3L1 is one of the defense mechanisms to cytokine mediated-inflammation. Although several studies are reported that serum CHI3L1 levels are higher in obese subjects (Kyrgios et al., 2012; Huang et al., 2014; Huang et al., 2016), it is still not clear whether CHI3L1 is involved in obesity especially abdominal obesity. Therefore, in this study, we investigated the contribution of CHI3L1 to development of obesity in Korean women through analysis of CHI3L1 SNPs and found that rs883125 is associated with visceral obesity.

\section{MATERIALS AND METHODS}

\section{Study population}

This study approved by Ethical Committee and the In- stitutional Review Board at Dermapro (IRB no. 1-220777B-N-02-DICN14002), and all participants provided informed written consent before participation. A total of 106 healthy volunteers (Korean females, aged $20 \sim 60$ years) were enrolled.

\section{Biological parameters}

BMI was calculated as weight $(\mathrm{kg}) /$ height $^{2}\left(\mathrm{~m}^{2}\right)$. Body fat contents $(\mathrm{kg})$, body fat rate $(\%)$ were obtained by bioelectrical impedance analysis using InBody 3.0 (Biospace, Seoul, Korea).

\section{SNP genotyping}

The experimental determination of SNP genotypes were conducted by the Theragen Etex Co., Ltd. For genotyping analysis, DNA was extracted from peripheral blood leukocytes by using Exgene ${ }^{\mathrm{TM}}$ Blood SV (GeneAll, Seoul, Korea). 125 ng DNA was mixed with $2.5 \mu \mathrm{L}$ of TaqMan OA GT Master Miz and used for the real-time quantitative PCR by TaqMan assay (Applied Biosystems, Calsbug, CA). The PCR mixture was loaded on the Open Array by using Accufill automated machine (Applied Biosystems, Calsbug, CA). The reaction ready Open Array chip was used in Quant Studio 12K (Applied Biosystems, Calsbug, CA). The real-time PCR reactions were performed at $95^{\circ} \mathrm{C}$ for $10 \mathrm{~min}, 40$ cycles at $92{ }^{\circ} \mathrm{C}$ for $15 \mathrm{sec}$, at $60^{\circ} \mathrm{C}$ for $1 \mathrm{sec}$. The genotyping was determined by the Vic and/or Fam fluorescent dye intensity.

\section{Animal experiments}

All animal procedures were approved by the Institutional Animal Care and Use Committee (IACUC) of Aestura Corporation and performed in accordance with their guidelines. 7-week-old C57BL/6J mice were purchased from the Central Laboratory Animal Inc. and maintained in a $12 \mathrm{~h}$ dark- $12 \mathrm{~h}$ light cycle chamber with controlled temperature of 22 $25^{\circ} \mathrm{C}$ and $40 \sim 50 \%$ humidity. For the HFD study, 8-weekold C57BL/6J male mice were fed a NCD or $60 \%$ HFD (Research Diet, Inc., D12492) for 16 weeks.

\section{Cell culture}

3T3-L1 cells were obtained from ATCC (CL-173). 3T3L1 cells were grown to confluence in Dulbecco's modified 
Eagle medium (DMEM; Hyclone, SH30243.01) supplemented with $10 \%$ bovine calf serum (Gibco, 26010-074). To induce adipocyte differentiation, at 2 days post-confluence, 3T3-L1 cells were incubated with DMEM containing 10\% fetal bovine serum (FBS; Hyclone, SH30919.03), $0.52 \mathrm{mM}$ 3-isobutyl-1-methylxanthine (Sigma Aldrich, I5879), $1 \mu \mathrm{M}$ dexamethasone (Sigma Aldrich, D1756), and $1 \mu \mathrm{g} / \mathrm{mL}$ insulin (Roche, 11376497001 ) for 2 days. Then, the culture medium was replaced with DMEM containing $10 \%$ FBS and $1 \mu \mathrm{g} / \mathrm{mL}$ insulin and the cells were cultured for 2 additional days. The culture medium was changed every two days with DMEM containing 10\% FBS.

For the inflammatory environmental mimicking experiments, differentiated 3T3-L1 adipocytes were incubated with or without $10 \mathrm{ng} / \mathrm{mL}$ TNF $\alpha$ (R\&D Systems, 210-TA) for $24 \mathrm{~h}$.

\section{RNA isolation and quantitative real-time PCR (qPCR)}

The RNA isolation and cDNA synthesis procedure were performed as described previously. Briefly, total RNA was isolated from mouse cells or cell lines with TRIzol Reagent (Ambion, 15596-018) and subjected to cDNA synthesis using RevertAid ${ }^{\mathrm{TM}}$ First Strand cDNA Synthesis (Thermo Scientific). mRNA relative amounts were measured using the CFX96 ${ }^{\mathrm{TM}}$ Real-Time System (Bio-Rad Laboratories Inc.) and calculated by normalization to the level of cyclophilin mRNA. The primer sequences that were used for quantitative real-time PCR analyses are provided in Supplementary Table 1.

\section{Statistical analysis}

The genetic association analysis used SPSS 15.0 and linear regression analysis.

In cell and mouse experiments, the results are presented as mean \pm SEM. Statistical significance was assessed by the two-tailed Student's $t$-test using GraphPad Prism 5.0 (GraphPad Software). When cells were used for experiments, three replicates per group were chosen. Differences were considered statistically significant at $P<0.05$.
Table 1. Demographic characteristics of the study subjects

\begin{tabular}{lr}
\hline \multicolumn{1}{c}{ Variables } & \multicolumn{1}{c}{ Values } \\
\hline Age $(\mathrm{y})$ & $44.51 \pm 6.22$ \\
Height $(\mathrm{cm})$ & $158.36 \pm 5.21$ \\
Weight $(\mathrm{kg})$ & $59.1 \pm 8.96$ \\
BMI $\left(\mathrm{kg} / \mathrm{m}^{2}\right)$ & $23.58 \pm 3.55$ \\
Fat mass $(\mathrm{kg})$ & $19.87 \pm 6.28$ \\
Skeletal muscle mass $(\mathrm{kg})$ & $21.2 \pm 2.43$ \\
Percent body fat $(\%)$ & $32.98 \pm 5.72$ \\
Waist-hip ratio & $0.9 \pm 0.04$ \\
\hline
\end{tabular}

\section{RESULTS}

Baseline characteristics of this study are presented in Table 1 .

\section{CHI3L1 SNP rs883125 is associated with abdominal obesity in Korean Women}

To identify polymorphisms in $C H I 3 L 1$ that are associated with obesity, we analyzed the subjects using a dominant model. The SNP rs883125 is associated with obesity, especially abdominal obesity (Table 2), whereas other CHI3L1 SNPs, rs2275353 and rs10399805, had no relation with obesity (data not shown). We found that rs $883125 \mathrm{G}$-allele was correlated with increased waist-hip ratio in Korean women, indicating that rs883125 contribute to visceral obesity.

\section{Inflammatory cytokines promotes Chi3ll expression in adipocytes}

To determine whether CHI3L1 contributes in visceral obesity, we analyzed the mRNA levels of Chi3ll in epididymal adipose tissue of diet-induced obese mice model. Consistent with previous reports (Ahangari et al., 2015), the transcripts of Chi3ll were elevated in adipose tissue of high fat diet (HFD)-induced obese mice (Fig. 1A).

To understand molecular mechanisms of obesity-mediated Chi3ll enhancement, we evaluated which factors influence to induction of Chi3l1 in adipocytes. Several evidences indicate that the levels of CHI3L1 are enhanced in inflammatory environments (Recklies et al., 2005; Di Rosa and Malaguarnera, 2016). Notably, TNF $\alpha$ significantly increased 
Table 2. Association of rs 883125 of $C H I 3 L 1$ and obesity-related quantitative traits among BMI, body fat contents, body fat rate and waist-hip ratio in collected Korean women

\begin{tabular}{|c|c|c|c|c|c|c|c|}
\hline & \multicolumn{4}{|c|}{ Genotype } & \multicolumn{3}{|c|}{ Dominant model } \\
\hline & $\mathrm{CC}$ & CG & GG & $\mathrm{CG}+\mathrm{GG}$ & $\beta$ & SE & $P$ value \\
\hline $\mathrm{n}$ & 62 & 43 & 3 & 46 & & & \\
\hline Age (years) & $45 \pm 6$ & $44 \pm 6$ & $43 \pm 8$ & $44 \pm 6$ & & & \\
\hline BMI $\left(\mathrm{kg} / \mathrm{m}^{2}\right)$ & $23.1 \pm 3.1$ & $24.2 \pm 3.9$ & $25.0 \pm 5.7$ & $24.3 \pm 4.0$ & 1.24 & 0.70 & 0.08 \\
\hline Body fat content (kg) & $19.0 \pm 5.4$ & $20.9 \pm 7.3$ & $23.8 \pm 7.4$ & $21.1 \pm 7.3$ & 2.06 & 1.24 & 0.10 \\
\hline Body fat rate (\%) & $32.2 \pm 5.2$ & $34.0 \pm 6.5$ & $34.5 \pm 3.6$ & $34.0 \pm 6.3$ & 1.72 & 1.13 & 0.13 \\
\hline Waist-hip ratio & $0.89 \pm 0.04$ & $0.90 \pm 0.05$ & $0.88 \pm 0.06$ & $0.9 \pm 0.05$ & 0.02 & 0.01 & 0.02 \\
\hline
\end{tabular}

the Chi3l1 gene expression in 3T3-L1 adipocytes suggesting that obesity-induced inflammatory responses could be a one of causing factor for enhancement of Chi3ll in adipocytes (Fig. 1B).

\section{DISCUSSION}

Characteristics of fat tissues are completely different according to its location (Ibrahim, 2010). Among various fat tissues, abdominal adipose tissue is closely involved in development of metabolic diseases due to its spatial position, closed to other organs, and its own properties, more proinflammatory than subcutaneous fat (Lee et al., 2013). Consequently, it is important to control the intra-abdominal adiposity. In this study, we identify that CHI3L1 rs883125 G-allele associates with higher waist-hip ratio, indicating rs883125 could be a risk factor for abdominal obesity in Korean women.

Previous studies have approached that mouse CHI3L1 is involved in obesity, especially abdominal obesity (Ahangari et al., 2015). In visceral adipose tissue of high fat diet-induced obese mice, the mRNA levels of Chi3ll are enhanced than visceral adipose tissue of normal chow diet-fed mice. In addition, Chi3l1 null mice have reduced visceral adipose tissue, which is composed with small adipocytes, compared with WT mice. On the other hand, Chi3ll overexpressed mice have increased visceral fat pad. Furthermore, serum CHI3L1 levels have positive correlation with obesity, especially abdominal obesity in human (Thomsen et al., 2015). Therefore, these results support our finding, which is CHI3L1
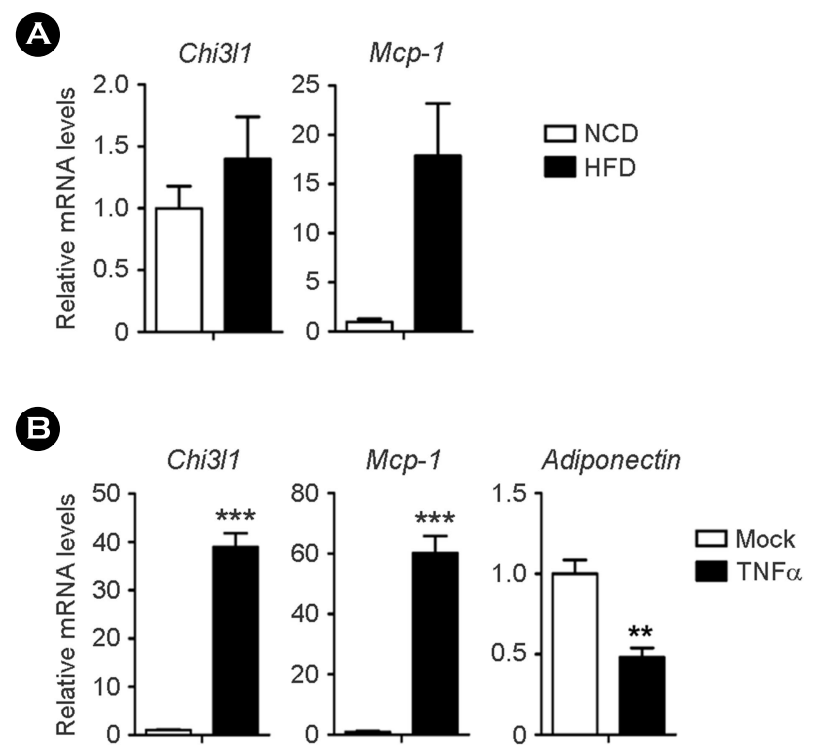

Fig. 1. Chi3ll is increased in adipose tissue of obese subjects and induced by inflammation in adipocytes. (A) C57BL/6J male mice were fed a NCD or $60 \%$ HFD for 16 weeks. Chi3ll and Mcp-1 mRNA levels were measured by qPCR. (B) Differentiated 3T3-L1 adipocytes were incubated with or without TNF $\alpha(10 \mathrm{ng} / \mathrm{mL})$ for $24 \mathrm{~h}$. The mRNA levels of Chi3ll, Mcp-1, and adiponectin were measured by qPCR. All graphs show mean value \pm SEM. $* * P<$ $0.01 ; * * * P<0.001$ in two-tailed Student's $t$-test.

contributes accumulation of fat in abdominal adipose tissue.

During weight gain, excess energy is accumulated in adipocytes as a fat resulting formation of enlarged adipocytes. Enlarged adipocytes secret various chemokines and cytokines to adapt the changed environment (Tilg and Moschen, 2006). Several immune cells are recruited into the visceral adipose tissue upon these signals from adipocytes and 
actively participate adipose tissue remodeling event (Sun et al., 2011). Even though the functions of CHI3L1 are not fully elucidated yet, it is known to have a closed relationship with inflammation and tissue remodeling via modulation of extracellular matrix (Kim et al., 2012; Di Rosa and Malaguarnera, 2016). Thus, obesity-induced enhancement of CHI3L1 might be involved in adipose tissue remodeling through regulation of inflammatory responses and adipocytes microenvironments.

A limitation of this study is the absence of serum CHI3L1 data. Therefore, it is difficult to conclude that rs 883125 involved in abdominal obesity through regulating CHI3L1 levels. Accordingly, it is clearly of importance to clarify whether rs883125 influences the expression, synthesis, and circulating levels of CHI3L1.

Collectively, our study suggests rs883125, one of SNPs of CHI3L1, is significantly associated with abdominal obesity in Korean women. And these genetic variants could be a biomarker for development of abdominal obesity.

\section{ACKNOWLEDGEMENTS}

None.

\section{CONFLICT OF INTEREST}

The authors have no conflicts of interest to disclose.

\section{REFERENCES}

Ahangari F, Sood A, Ma B, Takyar S, Schuyler M, Qualls C, Dela Cruz CS, Chupp GL, Lee CG, Elias JA. Chitinase 3-like-1 regulates both visceral fat accumulation and asthma-like th2 inflammation. Am J Respir Crit Care Med. 2015. 191: 746-757.

Choquet H, Meyre D. Genetics of obesity: What have we learned? Curr Genomics. 2011. 12: 169-179.

Chupp GL, Lee CG, Jarjour N, Shim YM, Holm CT, He S, Dziura JD, Reed J, Coyle AJ, Kiener P, Cullen M, Grandsaigne M, Dombret MC, Aubier M, Pretolani M, Elias JA. A chitinaselike protein in the lung and circulation of patients with severe asthma. N Engl J Med. 2007. 357: 2016-2027.

Despres JP, Lemieux I, Bergeron J, Pibarot P, Mathieu P, Larose E, Rodes-Cabau J, Bertrand OF, Poirier P. Abdominal obesity and the metabolic syndrome: Contribution to global cardiometabolic risk. Arterioscler Thromb Vasc Biol. 2008. 28: 1039
-1049 .

Di Rosa M, Malaguarnera L. Chitinase 3 like-1: An emerging molecule involved in diabetes and diabetic complications. Pathobiology. 2016. 83: 228-242.

Dina C, Meyre D, Gallina S, Durand E, Korner A, Jacobson P, Carlsson LM, Kiess W, Vatin V, Lecoeur C, Delplanque J, Vaillant E, Pattou F, Ruiz J, Weill J, Levy-Marchal C, Horber F, Potoczna N, Hercberg S, Le Stunff C, et al. Variation in fto contributes to childhood obesity and severe adult obesity. Nat Genet. 2007. 39: 724-726.

Esser N, Legrand-Poels S, Piette J, Scheen AJ, Paquot N. Inflammation as a link between obesity, metabolic syndrome and type 2 diabetes. Diabetes Res Clin Pract. 2014. 105: 141-150.

Frayling TM, Timpson NJ, Weedon MN, Zeggini E, Freathy RM, Lindgren CM, Perry JR, Elliott KS, Lango H, Rayner NW, Shields B, Harries LW, Barrett JC, Ellard S, Groves CJ, Knight B, Patch AM, Ness AR, Ebrahim S, Lawlor DA, et al. A common variant in the fto gene is associated with body mass index and predisposes to childhood and adult obesity. Science. 2007. 316: 889-894.

Herrera BM, Lindgren CM. The genetics of obesity. Curr Diab Rep. 2010. 10: 498-505.

Huang CJ, Beasley KN, Acevedo EO, Franco RL, Jones TL, Mari DC, Shibata Y. Chitin enhances obese inflammation ex vivo. Hum Immunol. 2014. 75: 41-46.

Huang CJ, Slusher AL, Whitehurst M, Wells M, Maharaj A, Shibata Y. The impact of acute aerobic exercise on chitinase 3-like protein 1 and intelectin-1 expression in obesity. Exp Biol Med (Maywood). 2016. 241: 216-221.

Ibrahim MM. Subcutaneous and visceral adipose tissue: Structural and functional differences. Obes Rev. 2010. 11: 11-18.

Kim MN, Lee KE, Hong JY, Heo WI, Kim KW, Kim KE, Sohn $\mathrm{MH}$. Involvement of the mapk and pi3k pathways in chitinase 3-like 1-regulated hyperoxia-induced airway epithelial cell death. Biochem Biophys Res Commun. 2012. 421: 790-796.

Krause SW, Rehli M, Kreutz M, Schwarzfischer L, Paulauskis JD, Andreesen R. Differential screening identifies genetic markers of monocyte to macrophage maturation. J Leukoc Biol. 1996. 60: $540-545$.

Kyrgios I, Galli-Tsinopoulou A, Stylianou C, Papakonstantinou E, Arvanitidou M, Haidich AB. Elevated circulating levels of the serum acute-phase protein ykl-40 (chitinase 3-like protein 1) are a marker of obesity and insulin resistance in prepubertal children. Metabolism. 2012. 61: 562-568.

Lee JH, Kim SS, Kim IJ, Song SH, Kim YK, In Kim J, Jeon YK, 
Kim BH, Kwak IS. Clinical implication of plasma and urine ykl-40, as a proinflammatory biomarker, on early stage of nephropathy in type 2 diabetic patients. J Diabetes Complications. 2012. 26: 308-312.

Lee MJ, Wu Y, Fried SK. Adipose tissue heterogeneity: Implication of depot differences in adipose tissue for obesity complications. Mol Aspects Med. 2013. 34: 1-11.

Lindgren CM, Heid IM, Randall JC, Lamina C, Steinthorsdottir V, Qi L, Speliotes EK, Thorleifsson G, Willer CJ, Herrera BM, Jackson AU, Lim N, Scheet P, Soranzo N, Amin N, Aulchenko YS, Chambers JC, Drong A, Luan J, Lyon HN, et al. Genomewide association scan meta-analysis identifies three loci influencing adiposity and fat distribution. PLoS Genet. 2009. 5: e1000508.

Ling H, Recklies AD. The chitinase 3-like protein human cartilage glycoprotein 39 inhibits cellular responses to the inflammatory cytokines interleukin-1 and tumour necrosis factor-alpha. Biochem J. 2004. 380: 651-659.

Loos RJ, Lindgren CM, Li S, Wheeler E, Zhao JH, Prokopenko I, Inouye M, Freathy RM, Attwood AP, Beckmann JS, Berndt SI, Prostate LC, Ovarian Cancer Screening T, Jacobs KB, Chanock SJ, Hayes RB, Bergmann S, Bennett AJ, Bingham $\mathrm{SA}$, Bochud $\mathrm{M}$, et al. Common variants near mc4r are associated with fat mass, weight and risk of obesity. Nat Genet. 2008. 40: 768-775.

McArdle MA, Finucane OM, Connaughton RM, McMorrow AM, Roche HM. Mechanisms of obesity-induced inflammation and insulin resistance: Insights into the emerging role of nutrional strategies. Front Endocrinol (Lausanne). 2013. 4: 52.

Meyre D, Delplanque J, Chevre JC, Lecoeur C, Lobbens S, Gallina S, Durand E, Vatin V, Degraeve F, Proenca C, Gaget S, Korner A, Kovacs P, Kiess W, Tichet J, Marre M, Hartikainen AL, Horber F, Potoczna N, Hercberg S, et al. Genome-wide association study for early-onset and morbid adult obesity identifies three new risk loci in european populations. Nat Genet.
2009. 41: 157-159

Recklies AD, Ling H, White C, Bernier SM. Inflammatory cytokines induce production of chi311 by articular chondrocytes. J Biol Chem. 2005. 280: 41213-41221.

Rehli M, Krause SW, Andreesen R. Molecular characterization of the gene for human cartilage gp-39 (chi311), a member of the chitinase protein family and marker for late stages of macrophage differentiation. Genomics. 1997. 43: 221-225.

Rehli M, Niller HH, Ammon C, Langmann S, Schwarzfischer L, Andreesen R, Krause SW. Transcriptional regulation of chi311, a marker gene for late stages of macrophage differentiation. J Biol Chem. 2003. 278: 44058-44067.

Sun K, Kusminski CM, Scherer PE. Adipose tissue remodeling and obesity. J Clin Invest. 2011. 121: 2094-2101.

Thomsen SB, Gjesing AP, Rathcke CN, Ekstrom CT, Eiberg H, Hansen T, Pedersen O, Vestergaard H. Associations of the inflammatory marker ykl-40 with measures of obesity and dyslipidaemia in individuals at high risk of type 2 diabetes. PLoS One. 2015. 10: e0133672.

Tilg H, Moschen AR. Adipocytokines: Mediators linking adipose tissue, inflammation and immunity. Nat Rev Immunol. 2006. 6: 772-783

Volck B, Price PA, Johansen JS, Sorensen O, Benfield TL, Nielsen HJ, Calafat J, Borregaard N. Ykl-40, a mammalian member of the chitinase family, is a matrix protein of specific granules in human neutrophils. Proc Assoc Am Physicians. 1998. 110: 351-360.

https://doi.org/10.15616/BSL.2018.24.1.23

Cite this article as: Kim AY, Jeong HW, Lee $\mathrm{JH}$, Choi JK, Kim JK, Hwang JS, Seo DB. Chitinase 3-Like 1 (CHI3L1) Polymorphism Contributes to Visceral Obesity and Obesity-related Inflammation Induces Chi3ll in Adipocytes. Biomedical Science Letters. 2018. 24: 23-29. 